\title{
EXPERIMENTAL ANALYSIS AND MODELING OF PROTON EXCHANGE MEMBRANE FUEL CELL
}

\author{
Sanjeev Doijode ${ }^{1}$, B.P. Yadav², B Sudheer Premkumar ${ }^{3}$ \\ ${ }^{I}$ JNTU Research scholar, Hyderabad, Department of Mechanical Engineering, REC Bhalki, 585328 \\ ${ }^{2}$ Prof, Department of Mechanical Engineering BIET Hyderabad \\ ${ }^{3}$ Prof \& Head Department of Mechanical Engineering, JNTU, Hyderabad, 500085
}

\begin{abstract}
Energy is the crucial input for the overall development of the country. The standard of living of a given country can be directly related to per capita energy consumption. The available non-renewable sources produces sewere pollution and depleting day by day whereas renewable sources are intermittent. What is required is a zero emission generation technology which gives cost effective and pollution free energy on large scale basis. Few technologies like hydrogen fuel cell are replacing by conventional sources.

This paper proposes a comparison of experimental results of PEM fuel cell with the theoretical results. The experimental set up is fabricated and established in the laboratories. After performance the results are compared with theoretical model. The proposed (Theoretical) model also developed, tested and compared. The developed model permits the simulation of PEM fuel cell with different parameter and allows the investigation of its behavior for any operating condition. The theoretical analysis (Modeling) is carried out by MATLAB software.
\end{abstract}

Keywords: PEM fuel cell, zero emission, modeling

\section{INTRODUCTION}

Energy crisis is due to the two reasons; firstly that the population of the world has increased rapidly and secondly the standard of living of human being has increased. The available renewable sources and non renewable sources are having its own demerits and obstacles and can not fulfill the present day demand of energy. In order to suit present day requirement a PEM fuel cell will be proved as a good alternative source. As a alternate source in this paper the comparisons of experimental and theoretical analysis of self built and established PEM fuel cell was carried out. Qualitative and quantitative information of this complex phenomenon is possible only on the base of mathematical models. . A mathematical analysis of these models is possible only after strong simplification. The proposed (Theoretical) model was developed, tested and compared. The developed model permits the simulation of PEM fuel cell with different parameter and allows the investigation of its behavior for any operating condition. The theoretical analysis (Modeling) is carried out by MATLAB software

\section{EXPERIMENTAL TEST RIG}

The experimental set up is fabricated and established in the laboratories. The experimental test rig to conduct performance test on pem fuel cell is shown in the fig 01. It comprises two circuit i.e. Hydrogen and oxygen supply circuit and electronic loading circuit. In the first circuit the hydrogen fuel will be supplied towards the anode side. A hydrogen cylinder with a pressure regulator ( 2 in no.) Will govern the supply of hydrogen to the pem fuel cell. One of the gauge indicates inside pressure of the tank and other indicates the pressure of hydrogen which is flowing towards fuel cell .one more pressure gauge is mounted to monitor the pressure in the path. For $12 \mathrm{w}$ fuel cell the inlet pressure of hydrogen is maintained between 0.4 to 0.5 bar. In the path of hydrogen flow a flow meter is installed to know the quantity of hydrogen being supplied to pem fuel cell. The flow meter is of rotameter type having the graduation from $25 \mathrm{ml}$ to $275 \mathrm{ml} / \mathrm{min}$ in a step of $25 \mathrm{ml}$. Next to flow meter an electric heater is installed in a path and its temperature can be changed with the variable input. The pem fuel cell is self breathing i.e. It has its own micro fan which is operated by extracting a small quantity of current and automatically it supplies a required quantity of oxygen to the cell. Hence it is not necessary to measure oxygen quantity. The second circuit is the electronic loading system. An electronic loading system (as shown in fig 02) is used to load the fuel cell. In the circuit a variable resistor, ammeter, voltmeter and wattmeter are provided. With the variation in the resistance the load will be coming on the fuel cell and with variation in resistance what will be the effect on performance of voltmeter, ammeter and wattmeter are studied.

\section{DESIGN AND DEVELOPMENT OF PEM FUEL CELL}

In this fuel cell setup 13 cell have been connected in series. Each cell is combined with other cell. Earlier the study of PEM fuel cell have been made with square section of MEA by many scientist but in this stack rectangular cross section bipolar plate and MEA is preferred and it is unique of its own kind. 


\subsection{Bipolar Plates}

Bipolar plates perform a number of functions within the PEM fuel cell. They have been used to distribute the fuel and oxidant within the cell, separate the individual cells in the stack, carry current and water away from each cell, humidify gases and keep the cells cool. Plate topologies and materials facilitate these functions.

\subsection{Anode and Cathode flow field Geometry}

The bipolar plates with parallel flow arrangement are made with the polyvinyl chloride and composite material having graphite deposition on it; the dimensions are $65 \times 20 \times 2.2$ $\mathrm{mm}$. It is thoroughly machined on CNC machine keeping width of each strip is about $0.7 \mathrm{~mm}$ and land is about 0.7 $\mathrm{mm}$. Totally 34 grooves flow field have been incorporated on the bipolar plate.
No separate cathode is provided in this system. Only one bipolar plate act as anode and cathode

MEA (Membrane Electrode assembly) The MEA is made up of perflorocarboxylic acid membrane and supported by composite material. The size of the MEA is chosen as $65 \mathrm{x}$ $20 \times 0.01 \mathrm{~mm}$. The MEA is perforated and is sandwiched between two bipolar plates along with the carbon diffusion layer. Thickness of gas diffusion layer is $0.22 \mathrm{~mm}$ with the platinum coating. Up till today the test is made up with the 5 cm square section MEA but here rectangular cross section MEA is chosen.

\subsection{Air Breather}

A separate breather to feed oxygen is incorporated in the system. It is micro exhaust fan operated on its own by generated current, it blows required quantity of air to the fuel cell and the same may be flowing.

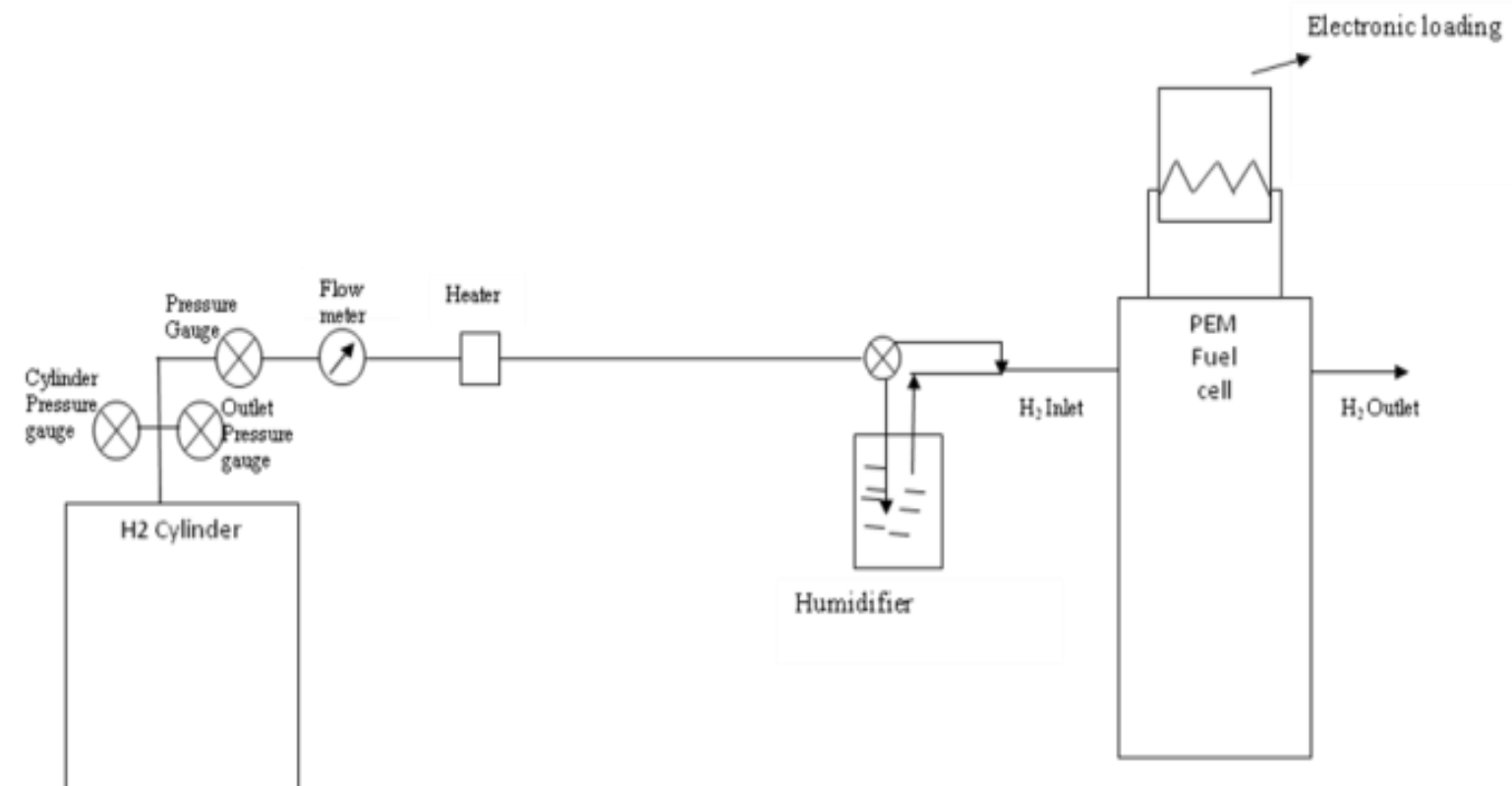

Fig 1 Experimental Setup

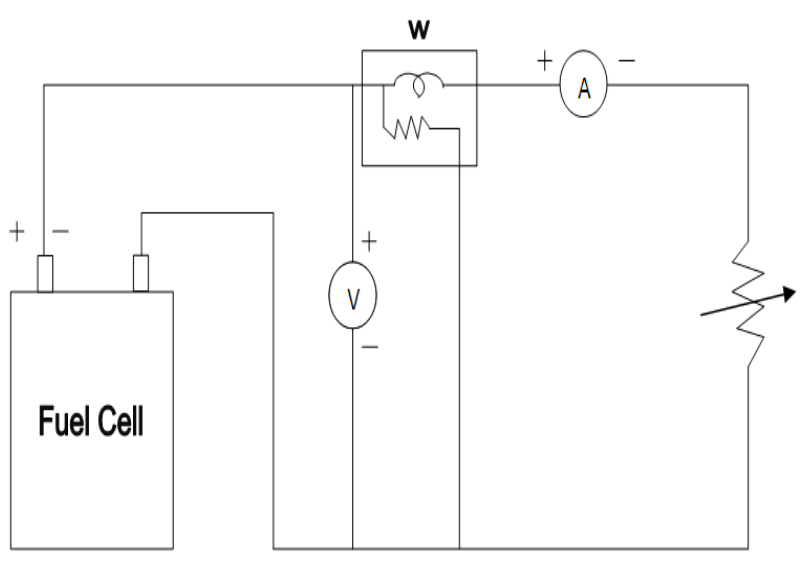

Fig 2 Electronic Loading System

\section{EXPERIMENTAL PROCEDURE}

The Performance test on fuel cell will be conducted in three ways.

1) By maintaining flow rate constant $200 \mathrm{ml} / \mathrm{min}$ and varying the load and

2) Flow rate is variable and load is constant

3) By changing the temperature of the fuel.

\subsection{By Maintaining Flow Rate Constant $200 \mathrm{ml} /$ min and varying the Load.}

In this test the fuel i.e. hydrogen is constantly supplied to PEM fuel cell from anode side Later the PEM fuel cell is loaded electronically with rheostat and ammeter by changing the resistance from $10 \mathrm{ohm}$ to $200 \mathrm{ohm}$. With the change in the resistance the change in the voltage and 
electric current is observed and also by changing the current, the variation in the voltage and power output and other parameter are recorded.

\subsection{Flow Rate and is Variable and Load is Constant}

Later it is tested with variation in fuel and constant load i.e. tested with variation in fuel in a step of $25 \mathrm{ml} / \mathrm{min}$ to $275 \mathrm{ml} / \mathrm{min}$, accordingly all other parameter such as voltage, current and power output are recorded

\subsection{By changing the Temperature of the Fuel}

The fuel cell will be also tested for change in temperature of fuel. . In this test the fuel cell is tested with change in fuel temperature i. e. (hydrogen) .Initially it is constantly supplied to PEM fuel cell at room temperature and then it is heated with the electric heater for different temperature and the variation in output and other parameters are recorded.

\section{THEROTICAL ANALYSIS OF PEM FUEL}

\section{CELL}

The theoretical analysis of PEM fuel cell is carried out with MAT LAB SIMULINK software.

The details are as follows

\subsection{PEM Fuel Cell Modeling}

The Electrochemical equations are at anode $\mathrm{H}_{2}=2 \mathrm{H}^{+}+2 \mathrm{e}^{-}$ at cathode $2 \mathrm{H}^{+}+2 \mathrm{e}^{-}+1 / 2 \mathrm{O}_{2}=\mathrm{H}_{2} \mathrm{O}+$ heat

Overall Reaction $\mathrm{H}_{2}+1 / 2 \mathrm{O}_{2}=\mathrm{H}_{2} \mathrm{O}+$ Heat

\subsection{Anode and Cathode Flow Model}

In this model the Oxygen usage and Hydrogen usage are calculated.

\subsection{Calculation of Oxygen}

Charge $=4 \mathrm{~F} \mathrm{X}$ amount of Oxygen

i.e. Four electrons are transformed for each mole of oxygen

Oxygen usage rate $=\mathrm{I} / 4 \mathrm{~F}$ moles $/ \mathrm{sec}$

Where $\mathrm{F}=$ faraday's constant $=96485 \mathrm{C}$

For N no of cells

Oxygen usage $=\mathrm{IN} / 4 \mathrm{~F}$ moles/sec

\subsection{Calculation of Hydrogen Usage}

From the basic reaction of fuel cell 2 electron are transferred for each mole of hydrogen so

$$
\text { charge }=2 \mathrm{~F} \mathrm{X} \text { amount of hydrogen }
$$

Hydrogen usage $=\mathrm{I} / 2 \mathrm{~F}$ moles $/ \mathrm{sec}$

Hydrogen usage $=\mathrm{I} / 2 \times 96485$

$=5.18 \times 10^{-5} \mathrm{I}$ moles $/ \mathrm{sec}$
Also we know that

$$
\begin{gathered}
\mathrm{PV}=\mathrm{NRT} \\
\therefore \mathrm{V} / \mathrm{N}=\mathrm{RT} / \mathrm{P}
\end{gathered}
$$

Where $\mathrm{V}=$ Volume

$\mathrm{N}=$ No of moles

$\mathrm{R}=\mathrm{Gas}$ constant $=8.314 \mathrm{KJ} / \mathrm{Kg} \mathrm{k}$

$\mathrm{T}=\mathrm{Temp}$ in Kelvin $=273+30$

$\mathrm{P}=0.4 \mathrm{bar}=0.4 \times 100 \mathrm{KN} / \mathrm{m}^{2}$

$$
\therefore \mathrm{V} / \mathrm{N}=8.314 \times 303 / 0.4 \times 100=62.9 \mathrm{Lit} / \mathrm{mol}
$$

$\mathrm{H}_{2}$ Usage $=5.18 \times 10^{-5} \mathrm{Ix} 62.9 \times 1000 \times 60$

$\mathrm{H}_{2}$ Usage $=19.5 \mathrm{I} \mathrm{mole} / \mathrm{min}$

$$
\therefore \mathrm{I}=\mathrm{H}_{2} \text { Usage } / 19.5 \mathrm{amp}
$$

Calculate I for different flow rate i.e. $25 \mathrm{ml} / \mathrm{min}$ in a step of $25 \mathrm{ml} / \mathrm{min}$. Then $\mathrm{I}_{1}, \mathrm{I}_{2}, \mathrm{I}_{3},---\mathrm{I}_{\mathrm{n}}$

Accordingly power $=\mathrm{V}_{\mathrm{FC}} \times \mathrm{I}$ is calculated for different values of $\mathrm{I}_{1}, \mathrm{I}_{2}, \mathrm{I}_{3}$, --- $\mathrm{I}_{\mathrm{n}}$ Keeping

$\mathrm{V}_{\mathrm{FC}}=2 \mathrm{v}$ then the plot of power $\mathrm{v} / \mathrm{s}$ hydrogen usage is plotted which is shown in figure.

\subsection{Stack Voltage Modeling}

The electrical characteristic of fuel cell is obtained in the form of polarization curve i.e. $\mathrm{V}_{\mathrm{FC}} \mathrm{v} / \mathrm{s}$ current density. The difference between $\mathrm{V}_{\mathrm{FC}}$ actual voltage and ideal voltage represents the losses in fuel cell

Generally three type of losses are considered

1) Activation losses ( $\Delta$ Vact $)$ - Due to slowness of the reaction

2) Ohmic losses ( $\Delta$ Vohmic $)$ - Due to internal losses by leakage

3) Concentration Losses $(\Delta V$ conc $)$ - Due to change in the concentration of reaction.

$$
\therefore \mathrm{V}_{\mathrm{FC}}=(\mathrm{Eo}-\mathrm{L})
$$

Where

$\mathrm{V}_{\mathrm{FC}}=$ Stack output voltage

Eo $=$ Cell potential obtained in an open circuit (No load)

$\mathrm{L}=$ Voltage losses $=\Delta \mathrm{Vact}+\Delta \mathrm{Vohmic}+\Delta \mathrm{V}$ conc i.e.

$$
\begin{gathered}
\mathrm{V}_{\mathrm{FC}}=\mathrm{Eo}-\mathrm{L} \\
=\text { Eo }-\Delta \text { Vact }-\Delta \text { Vohmic }-\Delta \text { Vconc }
\end{gathered}
$$

Eo $\quad=1482-0.000845 \mathrm{~T}+0.000431 \mathrm{Ln}\left(\mathrm{PH} \mathrm{P}_{\mathrm{o} 2}{ }^{0.5}\right)$ (Equation from Fuel Cell by Frano Babir)

Where $\mathrm{T}=\mathrm{Temp}$ in Kelvin $(273+30)$

$\mathrm{PH}=$ Partial pressure of Hydrogen $=1$

$\mathrm{P}_{\mathrm{o} 2}=$ Partial pressure of Oxygen $=0.21$

Cell potential $=\mathrm{Eo}=1.225 \mathrm{~V}$

$\mathrm{V}_{\mathrm{FC}}=\mathrm{Eo}-(\mathrm{RT} / \alpha \mathrm{F}) \operatorname{Ln}(\mathrm{i})-\mathrm{ir}+\mathrm{m} \exp \mathrm{ni}$ 
Where $\mathrm{R}=$ Gas constant $=8.3145 \mathrm{KJ} / \mathrm{Kg} \mathrm{K}$

$\mathrm{T}=\mathrm{Temp}$ in Kelvin $(273+30)$

$\alpha=0.5$ (coefficient asymmetric factor)

$\mathrm{F}=$ Faradays Constant

$\mathrm{r}=0.245 \Omega \mathrm{cm}^{2}$ (Ballard mark)

$\mathrm{m}=2.11 \times 10^{-5}$

$\mathrm{n}=8 \mathrm{~cm}^{2} / \mathrm{amp}$

For different values of $\mathrm{I}_{1}, \mathrm{I}_{2}, \mathrm{I}_{3}$, --- $\mathrm{I}_{\mathrm{n}}$ in step of 0.5 to 2.5 amp, $\mathrm{V}_{\mathrm{FC}}$ is determined.

Then plot of $\mathrm{V}_{\mathrm{FC}} \mathrm{v} / \mathrm{s}$ current (Polarization curve) is plotted which is shown in figure.

\section{COMPARISON OF EXPERIMENTAL AND THEORETICAL RESULTS}

\section{Variable Flow Rate}

\section{Experimental}

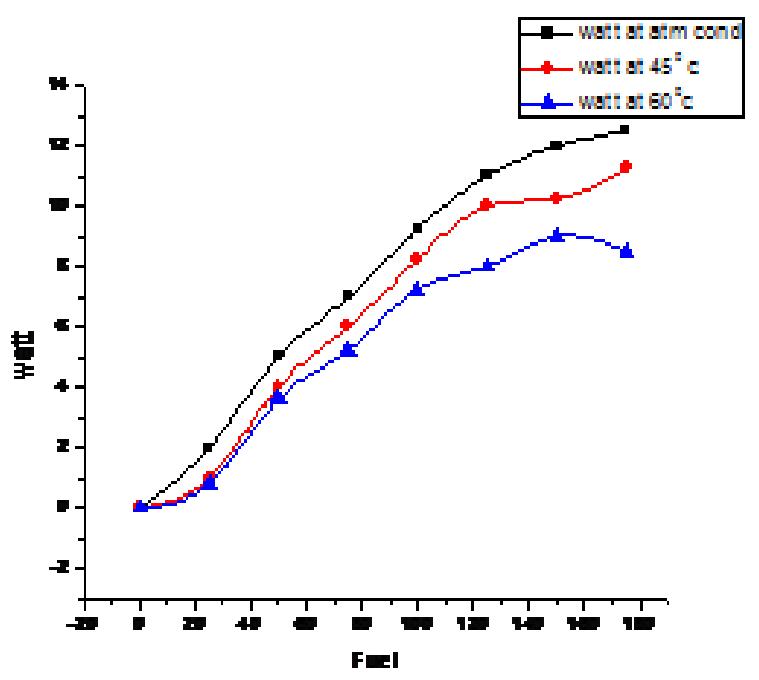

Fig 3 Variation of Power with Fuel

\section{Theoretical}

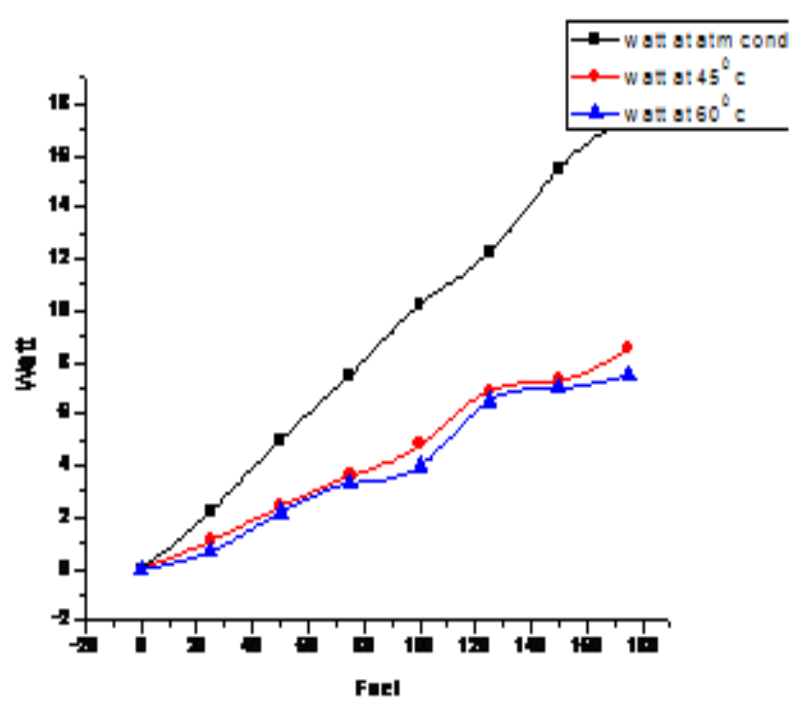

Fig 4 Variation of Power with Fuel

\section{Variable Flow Rate}

\section{Experimental}

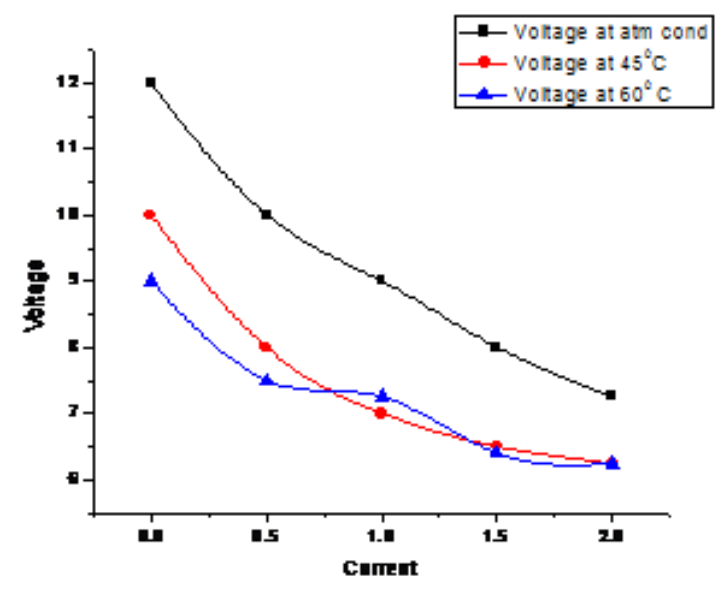

Fig 5 Variation of Voltage and current

\section{Theoretical}

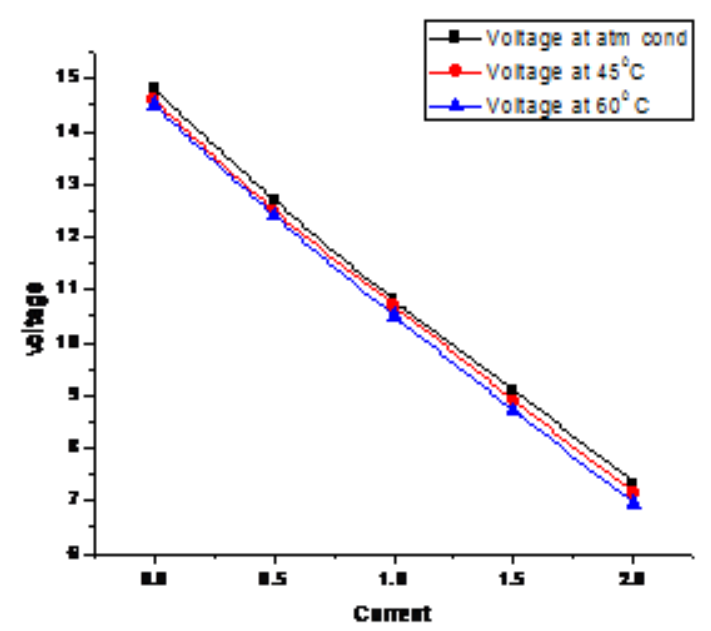

Fig 6 Variation of Voltage and current

\section{RESULTS AND DISCUSSIONS}

The experimental and theoretical analysis of PEM fuel cell is carried out. In experimental analysis the PEM fuel cell was tested with three conditions i.e. 1) By maintaining flow rate constant $200 \mathrm{ml} / \mathrm{min}$ and varying the load: 2) Flow rate is variable and load is constant 3) By changing the temperature of the fuel

The Figure 1 indicates how the performance of fuel cell affected by varying the flow rate and also it shows the effect of temperature change on the performance.

The curve represents that with enhancement of fuel supply the more power output can be extracted from PEM fuel cell. With low values of fuel the power output is lower. The plot also states that with the variation in fuel temperature the performance decreases. 
For atmospheric condition the output and fuel supply follows a linear relationship whereas with higher temperature of fuel the output value of cell falls lower and lower. Hence it is clearly indicated that the PEM fuel cell works satisfactorily at atmospheric condition Figure 2 shows the theoretical result. At atmospheric condition the theoretical value of power is almost similar up to $75 \mathrm{ml} / \mathrm{min}$ of fuel supply, after increasing the fuel supply above this value the theoretical power value is increasing by 1 or 1.5 watt. At $45^{\circ} \mathrm{c}$ and $60^{\circ} \mathrm{c}$ temp of fuel the theoretical value of power are declining and almost it is not matching. This indicates that the losses such as activation, ohmic and concentration losses are more in experimental results.'

The Figure 3 shows the variation of voltage and current (with purging). For the lower values of current, high output voltage was extracted whereas at higher value of current ,voltage falls and the heating effect of fuel decreases the current value and does not shows any improvement. The polarization curve shown in figure 4 for a stack as whole also follows similar trend as per the experimental results. The losses such as activation losses, ohmic losses and concentration losses increases with increase in current and ultimately decreases the cell potential

\section{CONCLUSION}

In this paper the comparisons of experimental and theoretical analysis of self built and established PEM fuel cell was carried out. The results are almost similar. However in the experimentation the losses such as activation losses, ohmic losses and concentration losses plays very important role and decreases the cell potential of stack.

\section{REFERENCES}

[1] Lu-Ying Chiu, bill Diong, and Randall S Gemmen “ An Improved Small signal Model of Dynamic Behavior of PEM Fuel Cells" IEEE Transactions on Industry Applications, Vol. 40 , July / August 2004.

[2] Jeferson M Correa, Felix A Farret, Luciane N Canha and Marcelo G Simoes, “ Electrochemical Based Fuel Cell Model Suitable for Electrical Engineering Automation Approach" IEEE 2004.

[3] Ararimeha " PEMFC Flow channel geometry optimization" Journal of Fuel Cell Science and Technology 2012, Vol. 9 / 011011 Copyright VC 2012 by ASME

[4] Shung zhai " Advance Study of Non uniform cell voltage distribution for a PEM fuel cell stack." Journal of Fuel Cell Science and Technology 2012, Vol. 9 / 011014 Copyright VC 2012 by ASME

[5] Chiun Hsun "The Numerical Study of geometric influence of flow channel pattern on performance of PEM fuel cell." " Journal of Fuel Cell Science and Technology 2012, Vol. 9 pp021015 Copyright VC 2012 by ASME

[6] G. Giacoppo "Stack Operation Using Composite Membrane-Electrodes Assemblies at 120 C" Journal of Fuel Cell Science and Technology JUNE
2012, Vol. 9 / 031005-1 Copyright VC 2012 by ASME

[7] Serhat Yesilyurt ,Jason B. Siegel "Modeling and Experiments of Voltage Transients of Polymer Electrolyte Membrane Fuel Cells With the DeadEnded Anode" Journal of Fuel Cell Science and Technology APRIL 2012, Vol. 9 / 0210121Copyright VC 2012 by ASME

[8] Chiun-Hsun Chen ,Tang-Yuan Chen ,Rong-Guie Peng "An Experimental Study on Micro Proton Exchange Membrane Fuel Cell" Journal of Fuel Cell Science and Technology JUNE 2012, Vol. 9 / 031001-1Copyright VC 2012 by ASME

[9] Shuang Zhai Su Zhou ,Pengtao Sun ,Fengxiang Chen ,Jigao Niu "Modeling Study of Anode Water Flooding and Gas Purge for PEMFCs" Journal of Fuel Cell Science and Technology JUNE 2012, Vol. 9 / 031007-1 Copyright VC 2012 by ASME

[10] John F. Hall , Dongmei Chen "The Effects of Membrane Properties and Structural Parameters on the Non-Minimum Phase Behavior of the PEM Fuel Cell Humidification System" Journal of Fuel Cell Science and Technology FEBRUARY 2012, Vol. 9 / 011005-1 Copyright VC 2012 by ASME

[11] Robbengle "Maximizing the use of Platinum Catalyst by ultra sonic spray application.” Journal of Fuel Cell Science and Technology FEBRUARY2012, Vol. 9 / 01450-1 Copyright VC 2012 by ASME

[12] Hao-Ming Chang, Min-Hsing Chang "Effect of Gas Diffusion Layer With Double-Side Microporous Layer Coating on Polymer Electrolyte Membrane Fuel Cell Performance" Journal of Fuel Cell Science and Technology APRIL 2013, Vol. 10 / 021005-1 Copyright VC 2013 by ASME

[13] Hao. Mingchang " Effect of Gas Diffusion layer with double side micro porous layer coating on PEM fuel cell performance.” Journal of Fuel Cell Science and Technology 2010, Vol. 7 / pp 0210003-1 to 8

[14] Sabit Adanur Synthesis and characterization of sulfonated polymide based membrane for PEM fuel cell. Journal of Fuel Cell Science and Technology Aug 2013, Vol. 10 / 041001-1to 5 Copyright VC 2013 by ASME 2013.

[15] Szu-Hua Wang Performance of the iridium oxide modified titanium bipolar plates for the light weight PEM fuel cell. Journal of Fuel Cell Science and Technology Aug 2013, Vol. 10 / 041002-1 to 6 Copyright VC 2013 by ASME 2013 